\title{
Tissue prognostic biomarkers in primary cutaneous melanoma
}

\author{
Mario Mandalà • Daniela Massi
}

Received: 10 October 2013 / Accepted: 3 December 2013

(C) Springer-Verlag Berlin Heidelberg 2014

\begin{abstract}
Cutaneous melanoma (CM) causes the greatest number of skin cancer-related deaths worldwide. Predicting $\mathrm{CM}$ prognosis is important to determine the need for further investigation, counseling of patients, to guide appropriate management (particularly the need for postoperative adjuvant therapy), and for assignment of risk status in groups of patients entering clinical trials. Since recurrence rate is largely independent from stages defined by morphological and morphometric criteria, there is a strong need for identification of additional robust prognostic factors to support decisionmaking processes. Most data on prognostic biomarkers in melanoma have been evaluated in tumor tissue samples by conventional morphology and immunohistochemistry (IHC) as well as DNA and RNA analyses. In the present review, we critically summarize main high-quality studies investigating IHC-based protein biomarkers of melanoma outcome according to Reporting Recommendations for Tumor Marker Prognostic Studies (REMARK)-derived criteria. Pathways have been classified and conveyed in the "biologic road" previously described by Hanahan and Weinberg. Data derived from genomic and transcriptomic technologies have been critically reviewed to better understand if any of investigated proteins or gene signatures should be incorporated into clinical practice or still remain a field of melanoma research. Despite a wide body of research, no molecular prognostic biomarker has yet been translated into clinical practice.
\end{abstract}

\section{Mandalà}

Unit of Clinical and Translational Research, Medical Oncology,

Department of Oncology and Hematology, Papa Giovanni XXIII

Hospital, Bergamo, Italy

\section{Massi $(\bowtie)$}

Division of Pathological Anatomy, Department of Surgery and Translational Medicine, University of Florence, Largo Brambilla, 3, 50134 Florence, Italy

e-mail: Daniela.massi@unifi.it
Conventional tissue biomarkers, such as Breslow thickness, ulceration, mitotic rate and lymph node positivity, remain the backbone prognostic indicators in melanoma.

Keywords Melanoma $\cdot$ Prognosis $\cdot$ Biomarkers $\cdot$ REMARK

\section{Introduction}

The global incidence of melanoma is increasing, with approximately 200,000 new cases and 65,000 melanoma-associated deaths each year $[1,2]$. Overall, cutaneous melanoma (CM) accounts for only $4 \%$ of all skin cancers; however, it causes the greatest number of skin cancer-related deaths worldwide [3].

As for many other cancers, mortality in melanoma is mainly related to metastatic spread to sites distant from the primary tumor and the prognostic parameters of the current melanoma American Joint Committee on Cancer (AJCC) staging system [4] represent the primary stratification criteria. Melanoma accurate prediction of prognosis is important to determine the need for further investigation, counseling of patients, to guide appropriate management (particularly the need for postoperative adjuvant therapy), and for assignment of risk status in groups of patients entering clinical trials.

However, according to AJCC staging system, the chances of relapse do not differ much between stage T2 and stage T3 patients; in addition also for melanoma detected at a very early stage $(\leq 1 \mathrm{~mm}, \mathrm{~T} 1 \mathrm{a}$ or $\mathrm{T} 1 \mathrm{~b})$ the risk of recurrence ranges between $1 \%$ and $12 \%$ [5]. Such clinical observations suggest that melanoma represents a heterogeneous group of diseases with varied clinical behavior and response to therapy and there is a strong need for identification of additional robust prognostic factors to support decision making processes, since recurrence rate is largely independent from stages defined by morphological and morphometric criteria. 
Novel technologies for molecular profiling, such as next generation DNA sequencing, have recently identified unique molecular profiles and mutation patterns in melanoma cells. At the RNA level, this has consisted of gene expression profiling using various robust and high throughput methodologies. In certain instances, markers identified using these platforms have been further examined and validated. However, at present, the contribution of such sophisticated and expensive techniques in predicting the prognosis of patients with melanoma, independently from conventional morphologically based tissue biomarkers, is not entirely clarified.

In 2000, Hanahan and Weinberg [6] reported six biological capabilities (hallmarks) acquired during the multistep development of human tumors: (i) sustaining proliferative signaling, (ii) evading growth suppressors, (iii) resisting cell death, (iv) enabling replicative immortality, (v) inducing angiogenesis, and (vi) activating invasion and metastasis [7]. In the last two decades, based on the emergence of new experimental data, two further hallmarks have been added to this list: (vii) reprogramming of energy metabolism and (viii) evading immune destruction. Such eight hallmarks, as distinctive and complementary capabilities that enable tumor growth and metastatic dissemination, may represent the logical framework in which organize and discuss the large amount of information related to prognosis beyond conventional prognostic biomarkers in $\mathrm{CM}$ patients.

To this aim, we performed an extensive "Medline" and Cancerlit literature review (1995-2013). Various combinations of search terms were used depending on the requirements of the database being searched. These terms included "melanoma," "prognosis," "prognostic," "prospective," "biomarkers," in combination with "genomic" or "postgenomic" or "immunohistochemical" or fluorescent in situ hybridization ("FISH") or comparative genomic hybridization ("CGH") or "molecular" or "incidence" or "management" or "recurrence" or "distant recurrence" or "survival", or "disease-free survival" or "trials" or "hallmarks" or "proliferative signaling" or "Ki67" or "phosphohistone H3" or "cyclin" or "growth suppressor" or "invasion" or "metastasis" or "lymphocytes" or "microenvironment" or "cell death" or "apoptosis" or "melanoma-specific survival," DNA microarray*, or RNA microarray*, or complementary DNA (cDNA) microarray, ${ }^{*}$ or gene-expression profil ${ }^{*}$, or gene expression profil*, or gene expression signature*, or gene expression signature*, or gene microarray*. Figure 1 shows the key advances in prognosis melanoma determinants from conventional and molecular features.

Because acral lentiginous, mucosal, and uveal melanomas display different pathologic, molecular, and clinical features from more common cutaneous superficial spreading and nodular histological subtypes, studies describing results on specific melanoma subgroup, such as acral lentiginous, mucosal, choroidal, or uveal melanomas, were excluded.
The quality of each eligible study was assessed for adherence to Reporting Recommendations for Tumor Marker Prognostic Studies (REMARK) criteria [8-10]. According to Gould Rothberg et al. [11], high-quality studies should satisfy each of the following six criteria: (1) prospective or retrospective cohort design with a clearly defined source population and justifications for all excluded eligible cases; (2) assay of primary cutaneous tumor specimens; (3) clear descriptions of methods for tissue handling and IHC, including antigen retrieval, selection, and preparation of both primary and secondary antibodies, as well as visualization techniques; (4) a clear statement on the choice of positive and negative controls; (5) statistical analysis using multivariable proportional hazards modeling that adjusted for conventional clinical prognostic factors; and (6) reporting of the resultant adjusted hazard ratios (HRs) and their $95 \%$ confidence intervals (CIs).

Herein, we followed the literature review strategy devised by Gould Rothberg [11] and Schramm and Mann [12], and we recorded additional eligible data for the subsequent 23 months.

\section{Conventional tissue prognostic biomarkers}

The clinical and histopathological characteristics that predict prognosis in primary $\mathrm{CM}$ have been studied for more than four decades. Presently, the following clinicopathologic prognostic markers have been consistently identified in several studies: age at diagnosis (with worse prognosis in older patients), male gender, growth phase (radial vs. vertical), Breslow thickness (BT), level of invasion, presence of ulceration and its extension, presence and density of tumorinfiltrating lymphocytes (TILs), presence of microsatellites, presence of vascular and/or lymphatic invasion, and the mitotic rate (MR).

However, when included in the more recent prognostic models [13-17], the absence or presence of regional nodal metastasis has been shown to be a strong prognostic factor that commonly negates all but a few of the variables associated with the primary tumor such as BT, MR, and ulceration.

According to the aim of this review, we will focus on conventional tissue prognostic biomarkers.

\section{Breslow thickness}

In 1970, Breslow [18] described a reproducible method of classification, based on the measurement in millimeters of the vertical thickness of the tumor. The BT is measured from the granular layer or, if the lesion is ulcerated, from the bottom of ulceration, up to the point of maximum infiltration. 
Timeline of key advances in prognostic melanoma determinants:

from conventional to molecular features

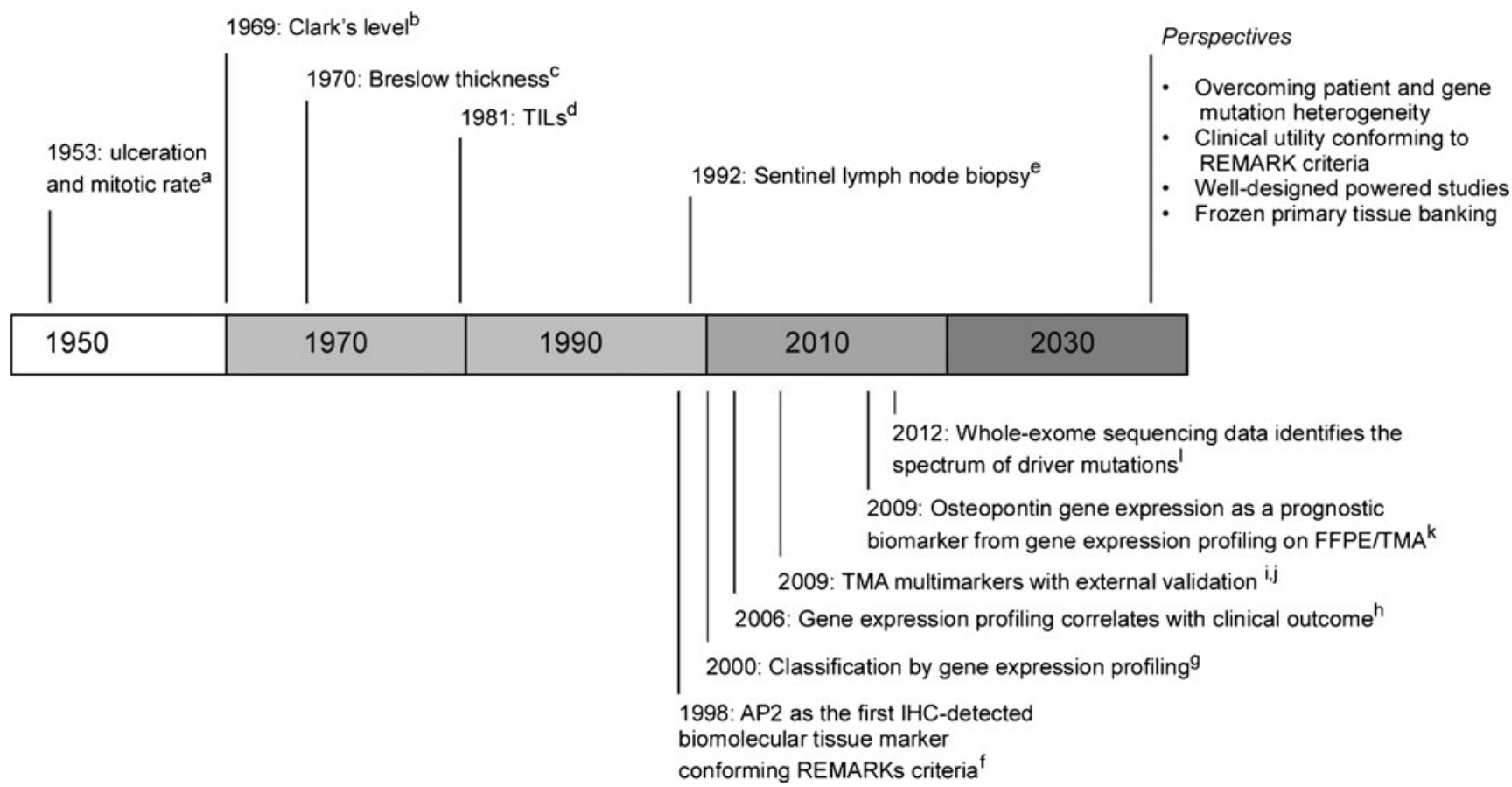

Fig. 1 Timeline of key advances in tissue prognostic biomarkers. a Allen AC, Spitz S [22]. b Clark et al. [35]. c Breslow [18]. d Day et al. [29]. e Morton et al. [19]. f Karjalainen et al. [72]. g Bittner et al. [87].

Adnexal involvement by melanoma is currently regarded as in situ disease, while in the case of periadnexal extension of melanoma, it is unclear from current evidence where the measurement of tumor thickness should be made to most accurately predict patient prognosis. It is generally agreed that thickness measurements should not be based on periadnexal extension, except when it is the only focus of invasion. In that case, BT may be measured from the inner layer of the outer root sheath epithelium or inner luminal surface of sweat glands, to the furthest extent of infiltration into the periadnexal dermis. The depth of extension of such foci beneath the granular layer of the epidermis may also be measured and reported (but not be recorded as the BT). Other problems in interpretation may arise when the nature of dermal cells is unclear (i.e., whether they represent melanoma or a preexisting naevus) and in cases of tumors with exophytic/ verruciform architecture. The thickness (measured from the top of the granular layer) of any zone of regression may also be recorded in the pathology report (but does not represent the true BT).

This classification system is more reproducible and reliable among pathologists and shows excellent correlation with mortality. The prognosis tends to worsen progressively in logarithmic function with increasing thickness, up to a thickness of $8 \mathrm{~mm}$ where it reaches a plateau, beyond which never reaches h Winnepenninckx et al. [90]. i Kashani-Sabet et al. [124]. j Gould Rothberg et al. [125]. k Conway et al. [96]. I Hodis et al. [20]

$100 \%$ mortality [4]. In a population-based study of 548 patients, tumor thickness was the most significant prognostic factor for survival of patients with localized CM [21]. More recently, detailed evaluation of $\mathrm{BT}$ data recorded in the AJCC melanoma staging database, has confirmed that BT correlates with a highly significant decline in 5- and 10-year survival rates survival. Among patients with $\mathrm{T} 1 \mathrm{melanomas}(\leq 1 \mathrm{~mm}$ thickness), the 10 -year survival was $92 \%$, but only $80 \%$, $63 \%$, and $50 \%$, in T2 (1.01 to $2.00 \mathrm{~mm}$, T3 (2.01 to $4.00 \mathrm{~mm}$ ) and $\mathrm{T} 4(>4 \mathrm{~mm})$ melanoma patients, respectively [4].

\section{Mitotic rate}

In 1953, Allen and Spitz [22] reported the poor survival of patients who had primary melanomas with a high MR, but it was not until nearly 50 years later that MR began to be identified as an independent prognostic factor [23, 24]. In 2003, Azzola et al. [23] demonstrated that cellular proliferation within the primary tumor, as reflected by its MR, was a more powerful prognostic indicator than ulceration in a 3,661patient, single-institution series.

In 2010, mitotic count was included in the pathological substaging of pT1 melanoma [4]. In the multivariate analysis, which formed the basis of these revised guidelines, mitotic 
count was the second strongest prognostic factor after tumor thickness in localized melanoma [25]. The strongest prognostic impact of mitotic count was seen in the group of pT1 tumors, although it was also a significant factor for thicker lesions. In the current staging system [4], it is recommended that mitoses should be assessed in all primary melanomas. The MR should be expressed as the number of mitoses $/ \mathrm{mm}^{2}$ and rated in the invasive component of the melanoma from the areas with increased mitotic activity ("hot spots") and extending to adjacent fields for a total area of $1 \mathrm{~mm}^{2}$. If there are no hot spots and mitoses are scattered randomly in the vertical growth phase component, in this case an area of $1 \mathrm{~mm}^{2}$ around a representative mitosis should be assessed and the result expressed as the number of mitoses $/ \mathrm{mm}^{2}$. When the invasive component is $<1 \mathrm{~mm}^{2}$ the simple presence or absence of a mitosis can be designated as at least $1 / \mathrm{mm}^{2}$ (mitogenic) or $0 / \mathrm{mm}^{2}$ (non-mitogenic).

As underlined by Scolyer and Thompson [26] MR should be recorded as the number of mitoses per $\mathrm{mm}^{2}$ and not per high power field (HPF), for at least three reasons: 1) comparison of MRs reported as n/HPF may not be reliable, because the field diameter of an HPF can vary greatly between microscopes; 2) there is an excellent inter-observer reproducibility when the hot spot method has been reported in a number of studies, whereas there is a poor inter-observer reproducibility for MR when it was recorded per HPF; 3) MR has been reported as an independent prognostic factor only when the hot spot method, as recommended by the current version of the AJCC staging manual, has been used.

\section{Ulceration}

The presence of ulceration must be microscopically evaluated in each primary melanoma specimen and the interpretation of melanoma ulceration is one of the most reproducible histopathological features. Ulceration is characterized by: i) fullthickness epidermal defect (including absence of stratum corneum and basement membrane); ii) evidence of reactive changes (fibrin deposition and neutrophils); iii) thinning, effacement, or reactive hyperplasia of the surrounding epidermis in the absence of trauma or a recent surgical procedure. It has been recently reported that extent of ulceration (measured either as diameter or percentage of tumor width) provides more accurate prognostic information than the mere presence of ulceration [27] but the evaluation of such parameters is not currently included in the pathological staging.

Thicker melanomas are more commonly ulcerated. In a population-based series, the incidence of melanoma ulceration in thin melanomas was only $6 \%$, while thick melanomas were ulcerated in $63 \%$ of cases [21]. Ulceration is a factor that predicts disease outcome independently of tumor thickness. The presence or absence of primary melanoma ulceration was the third most powerful survival predictor in the analysis of the current AJCC staging system [4]. Patients with ulcerated melanomas had a twofold higher estimated risk of dying due to melanoma compared to those with non-ulcerated tumors [4].

Interestingly, the presence of ulceration diminishes survival rates to the same level as for the patients with non-ulcerated melanomas of the next, larger thickness group. In the last AJCC melanoma staging database, 5-year survival was $79 \%$ for T3a non-ulcerated melanomas, and was $82 \%$ for T2b ulcerated melanoma. T4a non-ulcerated melanoma showed a 5 -year survival of $71 \%$, similar to that of T3b ulcerated melanoma with a $68 \%$ rate. $\mathrm{T} 4 \mathrm{~b}$ ulcerated melanoma were associated with a 5 -year survival of $53 \%$ [4].

\section{Tumor-infiltrating lymphocytes}

The metastatic process involves a complex series of interactions between the tumor and the host. Several data, first from animal models and then from studies in cancer patients, support the hypothesis that the immune system can recognize and reject tumors, suggesting that the ability of the tumor to evade immune recognition (immune surveillance) often determines the clinical course of the disease [28]. In melanoma tissue specimens, it has long been recognized that lymphocytes may be observed in intimate association with melanoma cells.

In 1981, Day et al. [29] reported a significantly better prognosis in patients with a marked lymphocytic infiltrate within primary CM than those with absent TILs. Clark et al. [30] later classified TILs according to their distribution and intensity as follows: (1) "brisk," if the lymphocytes were present throughout the substance of the vertical growth phase or were present and infiltrating across the entire base of the vertical growth phase; (2) "non-brisk," if the lymphocytes were in one focus or more foci of the vertical growth phase, either dispersed throughout or situated focally in the periphery; and (3) "absent," if there were no lymphocytes or if the lymphocytes were present but did not infiltrate the melanoma. Clark et al. [30] demonstrated that TILs had prognostic significance only if observed in the vertical growth phase but not in the radial growth phase.

The role of TILs as prognostic factors has been suggested by several reports, although conflicting data have been reported so far [21, 31-34]. Several reasons can be taken into account to justify such discrepancies: (1) inclusion of predominantly thin and radial growth phase melanomas vs. thick melanomas; (2) difficulty in some cases to grade a TILs infiltrate using the brisk and non-brisk categories; (3) studies may be underpowered to demonstrate an independent prognostic factor; and (4) scarce information regarding the immunology and pathobiology of TILs.

Recently, Azimi et al. [34] reported a four-tier system for grading TILs infiltrates based on the distribution and the density of TILs observed in the dermal component of the 
tumor. By using this classification, TIL grade has been reported as an independent predictor of survival and sentinel lymph node (SLN) status in patients with melanoma [34]. Although this study suggests that absence of TILs predicts SLN positivity and a poorer prognosis, melanoma progression still occurs, in most cases, despite lymphocytic infiltration. Such observation, in turn, implies the inability of TILs to mount an effective immune response. Whether TILs in such cases are functionally defective, incompletely activated, or anergic is still open to further investigation. Moreover, a better molecular characterization of TILs in PCM patients mandates further studies.

\section{Clark's level}

In 1969, Clark et al. [35], for the first time, formulated a histopathological classification of melanoma based on the level of invasion of the anatomical layers of the skin, demonstrating that the level of invasion was closely related to survival. In level I, melanoma is limited to the epidermis (in situ) and without risk of distant metastases. In level II, superficial extension to the papillary dermis, still guarantees an excellent prognosis. Invasion of level III (infiltration of the papillary dermis up to the reticular dermis) of IV (invasion of the reticular dermis) and V (invasion of subcutaneous fat) instead provides a gradual increase in the risk of metastasis and mortality. When considered as a single variable, Clark level of invasion is strongly associated with melanoma outcome. In a population-based series, patients with level II melanoma had $98.8 \% 5$-year survival, which dropped to $92.5 \%$ in patients with level III melanoma, $76.7 \%$ in patients with level IV melanoma, and $75 \%$ in patients with level V melanoma [21].

In the 2010 AJCC classification, Clark level of invasion is no longer incorporated as a staging criterion, since when MR is considered in the multivariate analysis, level is not an independent prognostic factor. Level has been replaced by MR in the 2010 AJCC classification for subclassifying pT1 lesions as $\mathrm{T} 1 \mathrm{a}$ or $\mathrm{T} 1 \mathrm{~b}$, but in the text and in a table comment of the AJCC chapter [4], Clark level IV or V is referred to as a tertiary criterion for $\mathrm{T} 1 \mathrm{~b}$ in cases with no ulceration and "if MR cannot be determined." Clark level should therefore be reported whenever it would form the basis for upstaging $\mathrm{T} 1$ lesions.

\section{Tumor growth phase}

$\mathrm{CM}$ originates from the proliferation of melanocytes in the basal layer of the epidermis and then expand radially at a later time and invades deep into the dermis. The radial phase is the not tumorigenic phase, characterized by the proliferation of melanocytes in the epidermis and/or in the papillary dermis, without formation of tumor nodule. The vertical growth phase is that where the tumorigenic melanoma acquires the ability to metastasize and is morphologically characterized by the presence of an expansive nodule larger than the intraepidermal aggregates and/or by the presence of mitotic figures in the invasive component.

\section{Tumor regression}

Regression is the segmental replacement of the melanoma by fibrosis, with increased vascularity and melanophages, and a lymphocytic infiltrate of variable density, with or without residual epidermal component. Regression can be defined as partial (involving less than $75 \%$ of the lesion) or extensive (involving $75 \%$ or more of the lesion). This phenomenon may be viewed into three temporal stages: early, intermediate, and late. In most reports assessing the prognostic significance of regression, intermediate, and late regression have not been differentiated and the prognostic significance of regression remains unclear. Some studies report that it indicates a worse prognosis (particularly in thin melanomas) [36, 37], whereas others did not report poorer outcome [38]. Difficulties in interpreting such studies include lack of a standardized diagnostic criteria and poor interobserver reproducibility.

\section{Lymphovascular invasion}

Vascular invasion is identified by the histopathological demonstration of melanoma cells within the lumina of blood vessels or lymphatics, or both. It is an uncommon finding in the excision specimens of primary $\mathrm{CM}$ (up to $8 \%$ ) [39], and is generally regarded as a marker of poor prognosis [40, 41]. IHC-detected LVI ranges from $16 \%$ to $47 \%[40,42,43]$ whereas BVI is uncommon in primary melanoma (3-4\% incidence) $[42,43]$. The presence lymphatic vessels invasion and blood vessels invasion detected by IHC has been associated to melanoma prognosis in many studies [40, 41, 43-47].

\section{Microsatellites}

Microsatellites are defined as microscopic and discontinuous cutaneous and/or subcutaneous metastases $>0.05 \mathrm{~mm}$ in diameter found on pathologic examination, adjacent to a primary melanoma (separated from the main invasive component by a distance of at least $0.3 \mathrm{~mm}$ ). Microsatellites are cutaneous or subcutaneous deposits of melanoma trapped within the lymphatics between the primary tumor and the regional lymph node basin. Microsatellitosis defines a subgroup of patients at higher-risk for regional and systemic recurrence. 


\section{Melanoma histotype}

The common melanoma histotypes (superficial spreading melanoma, nodular melanoma, acral lentiginous melanoma and lentigo maligna melanoma) are of little if any prognostic significance, independent of tumor thickness. Their interpretation is subjective and prone to interobserver variation.

\section{Lymph node positivity}

Melanoma commonly metastasizes by the lymphatic route, and the disease status of regional lymph nodes is considered as the most important prognostic indicator for patients with melanoma. In order to assess the regional lymph node status, SLN biopsy was developed as a standard procedure technique in patients deemed to have significant risk of clinically occult nodal metastases. The aim of this procedure is to detect micrometastatic lymphatic disease for selective lymphadenectomy. Depending on the extent of the pathology protocol used and the BT of the population studied, SN positivity ranges from $15 \%$ to $33 \%$ [48-50]. The more extensive sectioning protocols, like the standardized EORTC MG protocol, increases the detection rates of metastatic melanoma in SLN and also reveals larger deposits.

Among patients with localized melanoma undergoing SLN biopsy, the status of the sentinel node is the most important prognostic factor. According to the 2010 AJCC classification, clinically occult nodal metastases of melanoma found by SLNB or elective lymphadenectomy are defined as micrometastases, whereas nodal metastases found by clinical or radiologic evaluation and confirmed pathologically are classified as macrometastases.

Among patients with nodal metastases (Stage III), the number of metastatic nodes, clinical nodal status (macrometastases vs. micrometastases), the sentinel node tumor burden (represented by maximum diameter of the largest tumor lesion), and microanatomic tumor location within a sentinel node are the most important predictors of survival [51, 52]. In patients with nodal metastases, MR, primary ulceration, and primary thickness are all independent prognostic factors at multivariate analysis. In contrast, for patients with nodal macrometastases, the number of tumor-containing nodes and primary ulceration independently predict survival at multivariate analysis.

\section{IHC-based novel tissue biomarkers: independent or redundant prognostic classifiers?}

Validation issue strategy and related currently open issues

In the last two decades, several studies evaluated single biomarkers for outcome prediction in melanoma patients. The overall quality of the studies was generally poor if benchmarked against the REMARK guidelines [8]. In particular, a minority of the studies stated explicitly that they conformed to the REMARK checklist [11].

According to a recent meta-analysis, among 1,797 manuscripts reporting new tissue biomarkers for predicting outcome in melanoma, only 37 cohort studies, collectively describing 87 assays on 62 distinct proteins, conformed to the REMARK criteria by Gould Rothberg et al. [11].

In the present review, we updated data reported from Gould Rothberg et al. [11] and summarized the results of the most significant studies in Tables 1, 2, 3, 4, and 5. High-quality clinical and translational studies evaluating new potential IHC-based tissue biomarkers in melanoma, according to the REMARK criteria, are reported. Described biomarkers have been clustered according to the eight hallmarks described by Hanahan and Weinberg $[6,7]$ (Fig. 2).

Even taking into account that these studies met the REMARK criteria, a number of considerations should be raised to understand whether these biomarkers are fully ready to be transferred into clinical practice:

(i) small series: many of the studies included a limited number of patients and this has reduced the statistical power and widened the CIs, making extrapolation of results in the general patient population very difficult to implement;

(ii) heterogeneous/lack of staging information: most of the studies did not report the TNM classification and included patient cohort with heterogeneous clinical and pathological characteristics, such as patients with node positive and negative, that cannot be considered as a single entity neither from a clinical nor from a biological point of view;

(iii) retrospective studies: the design of the studies was generally based on retrospective series and limitations due to patient selection criteria cannot be ruled out;

(iv) external/internal validation: only 2 out of 63 studies reported an independent predictive molecular prognostic assay for primary melanoma, replicating the independent prognostic effect of molecular markers: (a) in a data set drawn from a completely different patient population, (b) across different tissue platforms (tissue microarray in the initial study cohort vs. tissue sections in the replication cohort), and (c) using different measurement techniques (pathologist scoring vs. digital imaging analysis);

(v) pre- and post-SNLB era: most prognostic models with long-term follow-up have been developed with patients who did not receive a SLN biopsy and these models have been based on clinical factors and histologic findings in the primary tumor. Thus, these results should not be extrapolated to patients treated in the era of SLNB; 


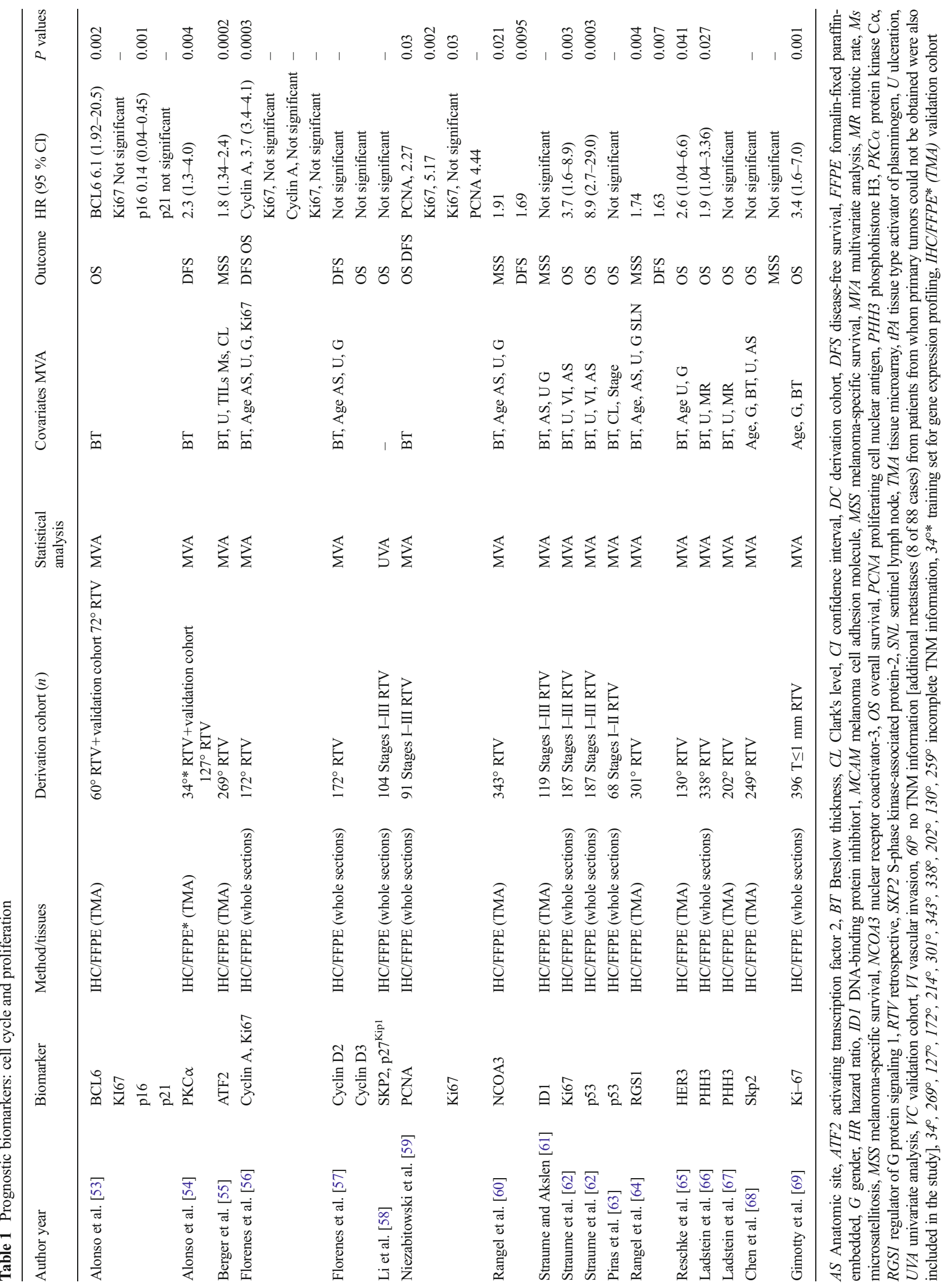


Table 2 Prognostic biomarkers: growth suppressors

\begin{tabular}{|c|c|c|c|c|c|c|c|c|}
\hline Author year & Biomarker & Method/tissues & $\begin{array}{l}\text { Derivation } \\
\text { cohort (n) }\end{array}$ & $\begin{array}{l}\text { Statistical } \\
\text { analysis }\end{array}$ & Covariates MVA & Outcome & $\operatorname{HR}(95 \% \mathrm{CI})$ & $\begin{array}{l}P \\
\text { values }\end{array}$ \\
\hline Berger et al. [70] & AP- $2 \alpha$ & IHC/FFPE (TMA) & $214^{\circ} \mathrm{RTV}$ & MVA & $\begin{array}{l}\text { BT, U, CL, TILs, } \\
\text { Ms }\end{array}$ & MSS & $2.14(1.22-3.76)$ & 0.0082 \\
\hline \multirow[t]{2}{*}{ Berger et al. [71] } & \multirow[t]{2}{*}{ HDM2 } & \multirow[t]{2}{*}{ IHC/FFPE (TMA) } & \multirow[t]{2}{*}{$200^{\circ} \mathrm{RTV}$} & \multirow[t]{2}{*}{ UVA } & & OS & \multirow[t]{2}{*}{-} & 0.03 \\
\hline & & & & & & MSS & & 0.03 \\
\hline \multirow[t]{2}{*}{ Karjalainen et al. [72] } & \multirow[t]{2}{*}{ AP-2 } & \multirow{2}{*}{$\begin{array}{l}\text { IHC/FFPE (whole } \\
\text { sections) }\end{array}$} & \multirow{2}{*}{$\begin{array}{l}273 \text { Stages I- } \\
\text { II RTV }\end{array}$} & \multirow[t]{2}{*}{ MVA } & \multirow[t]{2}{*}{ BT } & DFS & $3.12(1.42-6.82)$ & \multirow[t]{2}{*}{0.0026} \\
\hline & & & & & & OS & Not significant & \\
\hline \multirow[t]{2}{*}{ Korabiowska et al. [73] } & $\mathrm{Ku} 70$ & \multirow{2}{*}{$\begin{array}{l}\text { IHC/FFPE (whole } \\
\text { sections) }\end{array}$} & \multirow[t]{2}{*}{$76^{\circ} \mathrm{RTV}$} & \multirow[t]{2}{*}{ MVA } & \multirow[t]{2}{*}{ BT } & \multirow[t]{2}{*}{ OS } & $\mathrm{Ku} 700.87(0.82-0.92)$ & $<0.001$ \\
\hline & $\mathrm{Ku} 80$ & & & & & & $\mathrm{Ku} 800.85(0.79-0.92)$ & $<0.001$ \\
\hline McDermott et al. [74] & $\mathrm{nm} 23$ & $\begin{array}{l}\text { IHC/FFPE (whole } \\
\text { sections) }\end{array}$ & $145^{\circ} \mathrm{RTV}$ & $\begin{array}{l}\text { UVA } \\
\text { MVA }\end{array}$ & Stage & OS & Not significant & - \\
\hline Pacifico et al. [75] & $\mathrm{nm} 23$ & IHC/FFPE (TMA) & $\begin{array}{l}120 \text { Stages I- } \\
\text { III RTV }\end{array}$ & MVA & Age, BT, U, CL & OS & Not significant & - \\
\hline Soltani et al. [76] & MAP2 & $\begin{array}{l}\text { IHC/FFPE (whole } \\
\text { sections) }\end{array}$ & $37^{\circ} \mathrm{RTV}$ & MVA & Age, G, BT & DFS & 0.18 & 0.003 \\
\hline \multirow[t]{2}{*}{ Straume et al. [62] } & \multirow[t]{2}{*}{ p16 } & \multirow{2}{*}{$\begin{array}{l}\text { IHC/FFPE (whole } \\
\text { sections) }\end{array}$} & \multirow{2}{*}{$\begin{array}{l}167 \text { Stages I- } \\
\text { IIII RTV }\end{array}$} & \multirow[t]{2}{*}{ MVA } & \multirow{2}{*}{$\begin{array}{l}\text { BT, U, vascular } \\
\text { invasion, AS }\end{array}$} & OS & $2.5(1.5-4.2)$ & 0.0008 \\
\hline & & & & & & DFS & 2 & 0.007 \\
\hline \multirow[t]{2}{*}{ Li et al. [77] } & \multirow[t]{2}{*}{ ING4 } & \multirow[t]{2}{*}{ IHC/FFPE (TMA) } & \multirow[t]{2}{*}{$101^{\circ} \mathrm{RTV}$} & \multirow[t]{2}{*}{ MVA } & \multirow{2}{*}{$\begin{array}{l}\text { Age, G, BT, U, } \\
\quad \text { AS }\end{array}$} & OS & $2.50(1.09-5.74)$ & 0.031 \\
\hline & & & & & & MSS & $2.97(1.02-8.63)$ & 0.045 \\
\hline \multirow[t]{2}{*}{ Lin et al. [78] } & \multirow[t]{2}{*}{ SNF5 } & \multirow[t]{2}{*}{ IHC/FFPE (TMA) } & $88^{\circ} \mathrm{RTV}$ & MVA & Age, G, BT, U, & OS & $5.145(1.48-17.89)$ & 0.010 \\
\hline & & & & & AS & MSS & $4.637(1.15-18.63)$ & 0.031 \\
\hline Jonsson et al. [79] & RBM3 & IHC/FFPE (TMA) & 215 Stages I- & MVA & Age, G, MR, CL, & DFS & Not significant & - \\
\hline & & & III RTV & & BT & OS & $0.33(0.18-0.61)$ & 0.001 \\
\hline Jafarnejad et al. [80] & Sox4 & IHC/FFPE (TMA) & $89^{\circ} * \mathrm{RTV}$ & MVA & Age, $\mathrm{G}$ & OS & $1.9(1.078-3.362)$ & 0.026 \\
\hline & & & & & & MSS & $1.99(1.087-3.658)$ & 0.025 \\
\hline Chen et al. [81] & SATB1 & $\begin{array}{l}\text { IHC/FFPE (whole } \\
\text { sections) }\end{array}$ & $\begin{array}{l}47 \text { Stages I- } \\
\text { II RTV }\end{array}$ & MVA & BT & OS & $9.92(1.18-83.78)$ & 0.03 \\
\hline
\end{tabular}

$A P$-2 activator protein-2, $A S$ Anatomic site, $B T$ Breslow thickness, $C L$ Clark's level, $C I$ confidence interval, $D F S$ disease-free survival, $F F P E$ formalinfixed paraffin-embedded, $G$ gender, HDM2 human homolog of murine double minute $2, H R$ hazard ratio, ING4 inhibitor of growth $4, M A P-2$ microtubule-associated protein-2, MCAM melanoma cell adhesion molecule, $M S S$ melanoma-specific survival, $M V A$ multivariate analysis, $M R$ mitotic rate, $M s$ microsatellitosis, $M S S$ melanoma-specific survival, $n m 23$ nonmetastatic $23, N R$ not reported, $O S$ overall survival, $P K C \alpha$ protein kinase $\mathrm{C} \alpha$, $R B M 3$ RNA-binding motif protein 3, RTV retrospective, SATB1 special AT-rich sequence-binding protein-1, SNF5 core subunit of SWI/SNF chromatin remodeling complexes, $S N L$ sentinel lymph node, $S O X 4$ sry-related high-mobility group box transcription factor, TMA tissue microarray, $U$ ulceration, $U V A$ univariate analysis, $214^{\circ}, 200^{\circ}, 76^{\circ}, 145^{\circ}, 37^{\circ}, 101^{\circ}, 88^{\circ}, 89^{\circ}$ incomplete TNM information, $89^{\circ} *$ disease-free and overall survival in high-risk patients: $\mathrm{BT}>1.5 \mathrm{~mm}$

(vi) heterogeneous follow-up strategy: in retrospective trials the follow-up strategy has not been homogeneous for all enrolled patients, therefore a lead time bias due to different follow-up timing cannot be excluded;

(vii) intratumoral heterogeneity/serial tissue sections bias: all the reported studies measured the new biomarker in a tissue section that might have been distant from the original sections used to assess conventional prognostic histopathological factors. Future studies should include a protocol wherein these biomarkers are read on the same or adjacent serial sections for all lesions, in order to exclude biased results determined by tumor heterogeneity;

(viii) tissue microarray (TMA) vs. whole tissue sections: discrepancies are reported in results obtained in TMA vs. whole sections [66, 67]. TMA sections are less suitable for recording unevenly distributed markers in tumor tissues, therefore, the results obtained by TMA studies cannot be automatically translated into clinical practice where standard whole sections are used; and

(ix) undemonstrated clinical utility: although several studies demonstrated a strong correlation between a tissue biomarker and DFS or OS, this does not imply per se that the marker should be used to direct patient care. A new tissue biomarker should demonstrate clinical utility, namely, that the use of the marker test to drive patient management results in a favorable balance of benefits to harm, leading to superior outcomes compared with nonuse of the marker test. Improvement in outcome may relate to OS, DFS, quality of life, or cost of care. 
Table 3 Prognostic biomarkers: resisting cell death

\begin{tabular}{|c|c|c|c|c|c|c|c|c|}
\hline Author year & Biomarker & Method/tissues & $\begin{array}{l}\text { Derivation cohort } \\
(n)\end{array}$ & $\begin{array}{l}\text { Statistical } \\
\text { analysis }\end{array}$ & $\begin{array}{l}\text { Covariates MVA } \\
\text { BT, MR, U, NP }\end{array}$ & Outcome & $\mathrm{HR}(95 \% \mathrm{CI})$ & $\begin{array}{l}P \\
\text { Values }\end{array}$ \\
\hline Divito et al. [82] & Bcl-2 & $\begin{array}{l}\text { IHC/FFPE } \\
\text { (TMA) }\end{array}$ & $159^{\circ} \mathrm{RTV}$ & MVA & $\begin{array}{l}\text { Age, gender, BT, } \\
\text { U, CL }\end{array}$ & MSS & $\begin{array}{l}\mathrm{Bcl}-20.64 \\
\quad(0.48-0.86)\end{array}$ & 0.026 \\
\hline Ekmekcioglu et al. [83] & iNOS* & $\begin{array}{l}\text { IHC/FFPE } \\
\quad \text { (whole sections) }\end{array}$ & 132 RTV Stage III & MVA & $\begin{array}{l}\text { Age, gender, SNL } \\
\text { Status, In transit } \\
\text { disease }\end{array}$ & MSS & $\begin{array}{l}\text { iNOS PC } 4.63 \\
\quad(2.608 .25) \\
\text { iNOS SI } 7.69 \\
\quad(3.7615 .74)\end{array}$ & $\begin{array}{l}<0.0001 \\
<0.0001\end{array}$ \\
\hline Bachmann et al. [84] & $\mathrm{TNF} \alpha$ & $\begin{array}{l}\text { IHC/FFPE } \\
\text { (TMA) }\end{array}$ & $\begin{array}{l}133 \text { RTV Stages } \\
\text { I-III }\end{array}$ & MVA & $\begin{array}{l}\text { BT, U, Age, G, } \\
\text { SNL Status }\end{array}$ & MSS & $2.7(1.5-4.8)$ & 0.001 \\
\hline Piras et al. [85] & Survivin & $\begin{array}{l}\text { IHC/FFPE } \\
\quad \text { (whole sections) }\end{array}$ & 50 RTV Stages I-II & MVA & BT & DFS & $\begin{array}{l}\text { Survivin } 7.320 \\
(1.43,37.38)\end{array}$ & 0.017 \\
\hline Piras et al. [63] & Survivin & $\begin{array}{l}\text { IHC/FFPE } \\
\text { (whole sections) }\end{array}$ & 68 RTV Stages I-II & MVA & BT, CL, Stage & OS & Not significant & - \\
\hline Zhuang et al. [86] & GRP78 & $\begin{array}{l}\text { IHC/FFPE } \\
\text { (whole sections) }\end{array}$ & $92^{\circ} \mathrm{RTV}$ & MVA & $\begin{array}{l}\text { BT, U, Age, G, } \\
\quad \text { MR }\end{array}$ & $\begin{array}{l}\text { OS } \\
\text { DFS }\end{array}$ & Not significant & - \\
\hline
\end{tabular}

$B c l-2$ B-cell lymphoma 2, $B T$ Breslow thickness, $C I$ confidence interval, $C L$ Clark's level, $D F S$ disease-free survival, $F F P E$ formalin-fixed paraffinembedded, $G$ gender, $H R$ hazard ratio, GRP78 glucose-regulated protein 78, iNOS* inducible nitric oxide synthase: number of positive cells (PC) and staining intensity (SI), MCAM melanoma cell adhesion molecule, MSS melanoma-specific survival, $M V A$ multivariate analysis, $M R$ mitotic rate, $M S S$ melanoma-specific survival, $O S$ overall survival, $R T V$ retrospective, $S N L$ sentinel lymph node, $T M A$ tissue microarray, $T N F$ tumor necrosis factor, $U$ ulceration, $U V A$ univariate analysis, $159^{\circ}, 92^{\circ}$ incomplete TNM information

For the above considerations, notwithstanding that hundreds of such studies sought to assess the potential prognostic value of IHC-detected protein biomarkers in predicting the clinical course of melanoma patients, no biomolecular profile correlated with outcome can be considered ready to enter routine clinical practice.

\section{Genetic microarray signatures: impact on prognosis and technical shortcomings}

Genomic and transcriptomic technologies make the analysis of gene expression signatures and mutation status possible so that tumors may be classified more accurately with respect to diagnosis and prognosis.

In their pioneering study, Bittner et al. [87] reported, through gene expression profiling analysis, two molecular subtypes of metastatic melanoma with possible prognostic significance. Since the publication of this first signature in the late 1990s, high-throughput gene expression analysis has revolutionized genetics over the last 13 years. Nevertheless, scientific excitement about the attractiveness of molecular technologies has been temperate by results that did not reach scientific evidence of clinical benefit. Furthermore, it is not still clear whether these expensive and complex techniques can be applied extensively for routine use.

Recently, molecular studies reporting gene expression profiles in melanoma have been reviewed [88]. From more than 100 articles available in the literature, only 14 gene expression studies that identified biomarkers associated with prognosis fulfilled the REMARK criteria [54, 89-100, 124]. These studies included patients with different BT, patients with superficial spreading and nodular melanoma, with or without SLN involvement, with different follow-up strategy and treatment in the adjuvant and metastatic setting and heterogeneous rationale of dataset construction. Samples were obtained from different sources: primary tumor, lymph nodes, and distant metastases. Only 4 out of 14 studies provided estimated effects with CIs from an analysis in which the marker and standard prognostic variables were included. Furthermore, most of these studies did not describe the flow of patients through the study, including the reasons for dropout. Most of the above reported reasons may partially justify the poor signature overlap across these 14 studies. However, other technical reasons should be considered.

MHC II molecules were found to correlate with prognosis in two studies [89, 93]. However, biopsies with infiltrated metastatic lymph nodes were evaluated in both studies and thus a small amount of residual lymphoid tissue, expressing HLA class II molecules, could have been present.

Tumor heterogeneity, namely, non-malignant and malignant melanocytes for DNA and/or RNA-based studies is a critical issue in polymerase chain reaction and cDNA arrays in which cells are disrupted to release genomic material from different cell types. The scarcity of tumor samples amplifies this confounding heterogeneity.

Furthermore, as compared to other solid tumors technical limitations in the availability of frozen tissue from primary CM-limited large gene expression profiling study from patients with long clinical follow-up, since it is custom to fix and embed in paraffin for histologic diagnosis the whole primary tumor.

Finally, there is evidence that mutation frequency varies by several orders of magnitude across patients with a given 


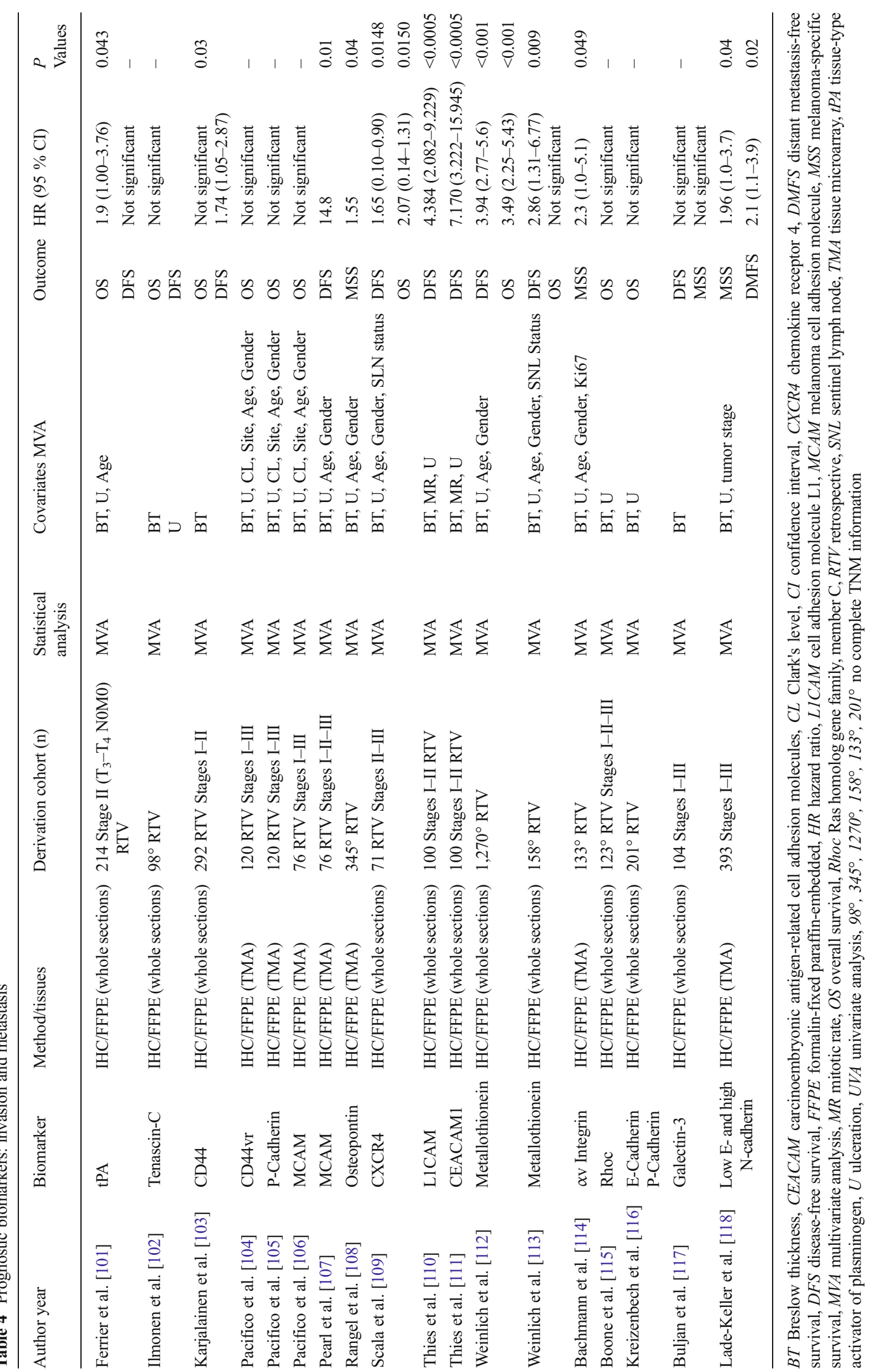




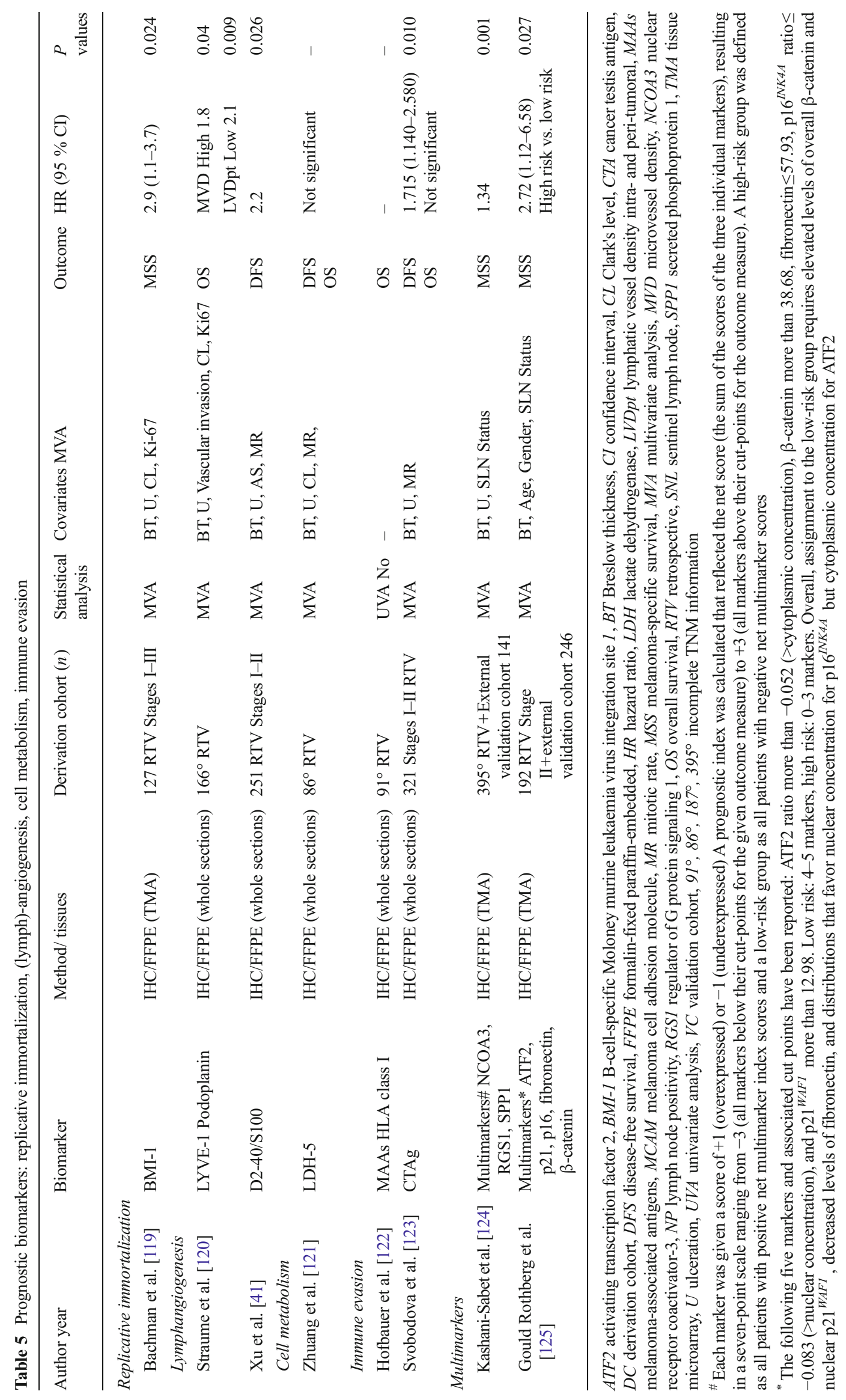


Fig. 2 Main prognostic biomarkers conformed to the REMARK criteria reported in primary cutaneous melanoma patients and clustered according to hallmarks of cancer (Hanahan and Weinberg [7])

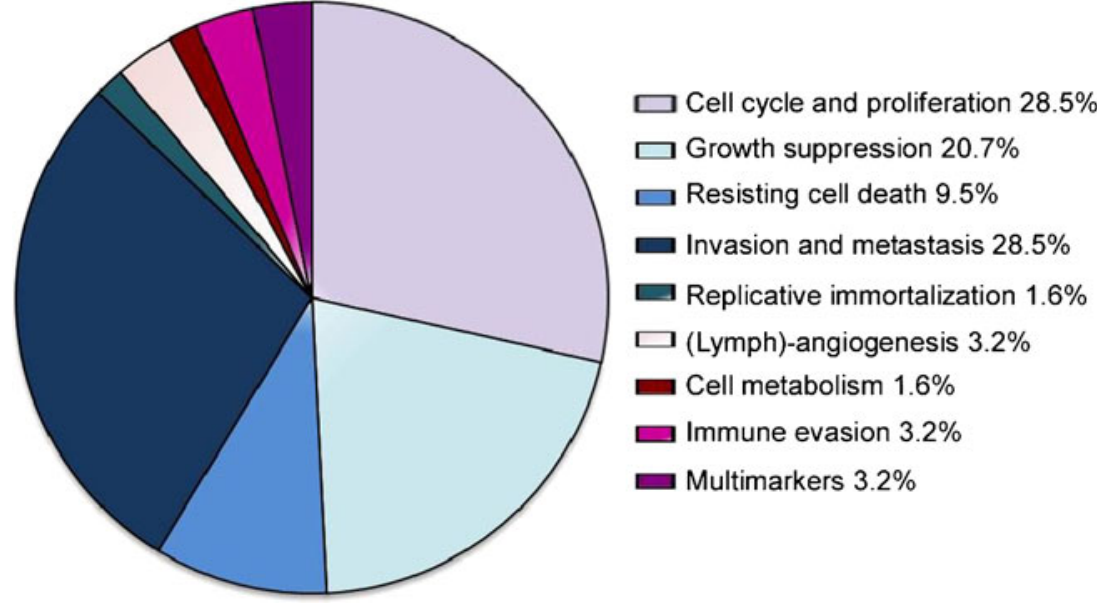

cancer type and there is also variability among individual patients. These issues should be considered since current analytic methods could fail to account for mutational heterogeneity that affects the mutational background mutation rate [126].

\section{BRAF/NRAS: prognostic or predictive biomarkers?}

In patients with $\mathrm{CM}$, the AJCC staging criteria and currently used conventional prognostic models define subgroups of patients with different survival. However, within each patient subgroup, there still remains significant variability in clinical outcome. With the advancement of cancer genomics, it is clear that the genetic features of melanoma are heterogeneous and relevant to melanoma progression. Driver mutations of genes associated with the development of tumor cells, such as genes controlling cell division and apoptosis, invasion and metastasis, growth suppressor, and immune evasion have been identified in melanoma.

There is increasing evidence that $\mathrm{CM}$ is a genetically heterogeneous disease, and genetic alterations can be used to classify primary tumors into distinct subtypes. Loss of PTEN (25-50\%) and amplification of microphthalmia-associated transcription factor (MITF; $10-15 \%)$, CDK2/4 (20\%), and Cyclin D (30 \%) are frequently observed [127]. Mutation of cKIT occurs in $20-40 \%$ of acral and mucosal tumors [127]. More than half of primary $\mathrm{CM}$ show activating mutations of NRAS (15\%) or BRAF proto-oncogenes (50\%), which are components of the RAS-RAF-MEK-ERK signal transduction pathway [128]. Gain-of-function BRAFV600E mutation accounts for more than $70 \%$ of the BRAF alterations described in melanoma, with alternative point mutations at the same position (V600D, V600K, V600R) contributing as following: 10-30 \% are V600K, while V600R mutations constitute approximately $3-7 \%$ of all BRAF mutations.
Several studies evaluated the impact of NRAS and/or BRAF mutations on outcome in patients with primary $\mathrm{CM}$ [129]. In an attempt to correlate BRAF and NRAS mutational status with features known to influence tumor behavior including age, gender, Breslow depth, Clark level, MR, the presence of ulceration and AJCC staging Ellerhorst et al. [130] performed a microdissection of 223 primary melanomas. In this study, survival did not differ between Stage III patients whose primary tumors did or did not carry mutations, even though the mutated tumors tended to produce larger volume nodal disease.

Edlundh-Rose et al. [131] analyzed a total of 294 melanoma tumors from 219 patients. Mutations in BRAF exons 11 and 15 were identified in $156(53 \%)$ tumors and NRAS mutations in $86(29 \%)$ tumors. BRAF and NRAS mutations did not influence the overall survival from time of diagnosis.

BRAF mutation has been tested in 197 Australian patients with metastatic melanoma in order to identify clinicopathologic variables correlated with BRAF mutation status; furthermore, a survival analysis was conducted [132]. Features of the antecedent primary melanoma significantly associated with a BRAF mutation were the presence of mitoses, single or occult primary melanoma, truncal location, and age at diagnosis of primary tumor $\leq 50$ years. BRAF mutation was found to be prognostically relevant in metastatic melanoma but not in primary CM. Furthermore, the presence of mutant BRAF did not seem to have any impact on the disease-free interval from diagnosis of first-ever melanoma to first distant metastasis.

Recently, Si et al. [133] reported the prevalence and the prognostic relevance of BRAF V600E in 396 Chinese patients. This retrospective study suggested that BRAF/NRAS may be independent adverse prognostic factors in melanoma. However, mucosal and unknown primary melanoma have been included; furthermore, it is not clear whether these data obtained in Chinese patients can be extrapolated in Caucasian population. 
Finally, Devitt et al. [134] reported a prospective cohort of 249 patients. When compared to WT, multivariate analysis of melanoma-specific survival (MSS) identified NRAS mutations as an adverse prognostic factor but not BRAFV600E mutations. However, only eight events occurred for NRAS analysis; therefore, further study is warranted with a larger prospective cohort to fully address this issue.

A recent meta-analysis found a prognostic effect for BRAF mutation [129]. However, in this study, patients with limited as well as metastatic disease were included in the analysis.

Overall, the take-home message from the above-reported studies is that BRAF and NRAS mutations are not independent prognostic biomarkers in patients with limited (Stages IIII) radically resected primary $\mathrm{CM}$.

\section{Perspective}

The past decades witnessed important molecular advances in the field of melanoma research. Despite a wide body of research, no molecular prognostic biomarker has yet been translated into clinical practice. Several biomolecular prognostic factors have been reported but a limited number has been validated in independent datasets with sufficient followup, and few studies include complete clinical and pathological information. Accordingly, at present, no single molecular biomarker is routinely or broadly used to guide patient care decisions. Conventional tissue biomarkers, such as BT, ulceration, mitotic rate, and lymph node positivity, remain the backbone prognostic indicators in melanoma.

More recently, the powerful and independent prognostic efficacy of combined marker derived from gene expression profiling analyses has been demonstrated. The prognostic role of multimarker molecular assays, which partially capture melanoma heterogeneity and describe signalling pathways important in melanoma biology, has been validated in independent dataset $[124,125,135]$. Thus, in the forthcoming years, validated multimarker molecular assays will emerge to supplement available clinicopathological parameters for refining prognosis in melanoma patients.

Several issues remain open and represent a call to action for future research:

(1) To improve the quality of clinical research and specifically the adherence to higher standards for reporting prognostic translational biomarker studies;

(2) To identify molecular markers establishing clinical utility according to REMARK recommendation; and

(3) To develop methods that would correct for patient- and gene-specific mutational heterogeneity and be capable to identifying much shorter lists of plausible biological genes useful for clinical decision-making process.
Conflict of interest None

\section{References}

1. Garbe C, Peris K, Hauschild A, Saiag P, Middleton M, Spatz A, Grob JJ, Malvehy J, Newton-Bishop J, Stratigos A, Pehamberger H, Eggermont A (2010) Diagnosis and treatment of melanoma: European consensus-based interdisciplinary guideline. Eur J Cancer 46:270-283

2. World Health Organization. Skin cancers (2013) http://www.who. int/uv/faq/skincancer/en/index1.html. Accessed 28 June 2013

3. Jemal A, Siegel R, Xu J, Ward E (2006) Cancer statistics, 2006. CA Cancer J Clin 56:106-130

4. Balch CM, Gershenwald JE, Soong SJ, Thompson JF, Atkins MB, Byrd DR, Buzaid AC, Cochran AJ, Coit DG, Ding S, Eggermont AM, Flaherty KT, Gimotty PA, Kirkwood JM, McMasters KM, Mihm MC Jr, Morton DL, Ross MI, Sober AJ, Sondak VK (2009) Final version of 2009 AJCC melanoma staging and classification. J Clin Oncol 27:6199-6206

5. Gimotty PA, Guerry D, Ming ME, Elenitsas R, Xu X, Czerniecki B, Spitz F, Schuchter L, Elder D (2004) Thin primary cutaneous malignant melanoma: A prognostic tree for 10-year metastasis is more accurate than American joint committee on cancer staging. $\mathrm{J}$ Clin Oncol 22:3668-3676

6. Hanahan D, Weinberg RA (2000) The hallmarks of cancer. Cell 100:57-70

7. Hanahan D, Weinberg RA (2011) Hallmarks of cancer: The next generation. Cell 144:646-674

8. McShane LM, Altman DG, Sauerbrei W, Taube SE, Gion M, Clark GM, Statistics Subcommittee of the NCI-EORTC Working Group on Cancer Diagnostics (2005) Reporting recommendations for tumour marker prognostic studies (REMARK). Br J Cancer 93:387391

9. McShane LM, Hayes DF (2012) Publication of tumor marker research results: The necessity for complete and transparent reporting. J Clin Oncol 30:4223-4232

10. Altman DG, McShane LM, Sauerbrei W, Taube SE (2012) Reporting recommendations for tumor marker prognostic studies (REMARK): Explanation and elaboration. PLoS Med 9:e1001216

11. Gould Rothberg BE, Bracken MB, Rimm DL (2009) Tissue biomarkers for prognosis in cutaneous melanoma: A systematic review and metaanalysis. J Natl Cancer Inst 101:452-474

12. Schramm SJ, Mann GJ (2011) Melanoma prognosis: A REMARKbased systematic review and bioinformatic analysis of immunohistochemical and gene microarray studies. Mol Cancer Ther 10:1520 1528

13. Callender GG, Gershenwald JE, Egger ME, Scoggins CR, Martin RC 2nd, Schacherer CW, Edwards MJ, Urist MM, Ross MI, Stromberg AJ, McMasters KM (2012) A novel and accurate computer model of melanoma prognosis for patients staged by sentinel lymph node biopsy: Comparison with the American joint committee on cancer model. J Am Coll Surg 214:608-617, discussion 617-619

14. Soong SJ, Ding S, Coit D, Balch CM, Gershenwald JE, Thompson JF, Gimotty P (2010) Predicting survival outcome of localized melanoma: An electronic prediction tool based on the AJCC melanoma database. AJCC melanoma task force. Ann Surg Oncol 17: 2006-2014

15. MacKie RM, Aitchison T, Sirel JM, McLaren K, Watt DC (1995) Prognostic models for subgroups of melanoma patients from the Scottish melanoma group database 1979-86, and their subsequent validation. Br J Cancer 71:173-176

16. Schuchter L, Schultz DJ, Synnestvedt M, Trock BJ, Guerry D, Elder DE, Elenitsas R, Clark WH, Halpern AC (1996) A prognostic 
model for predicting 10 -years survival in patients with primary melanoma. The Pigmented Lesion Group. Ann Intern Med 125: 369-375

17. Sahin S, Rao B, Kopf AW, Lee E, Rigel DS, Nossa R, Rahman IJ, Wortzel H, Marghoob AA, Bart RS (1997) Predicting ten-year survival of patients with primary cutaneous melanoma: A corroboration of a prognostic model. Cancer 80:1426-1431

18. Breslow A (1970) Thickness, cross-sectional areas and depth of invasion in the prognosis of cutaneous melanoma. Ann Surg 172: 902-908

19. Morton DL, Wen DR, Wong JH, Economou JS, Cagle LA, Storm FK, Foshag LJ, Cochran AJ (1992) Technical details of intraoperative lymphatic mapping for early stage melanoma. Arch Surg 127(4):392-399

20. Hodis E, Watson IR, Kryukov GV, Arold ST, Imielinski M, Theurillat JP, Nickerson E, Auclair D, Li L, Place C, Dicara D, Ramos AH, Lawrence MS, Cibulskis K, Sivachenko A, Voet D, Saksena G, Stransky N, Onofrio RC, Winckler W, Ardlie K, Wagle N, Wargo J, Chong K, Morton DL, Stemke-Hale K, Chen G, Noble M, Meyerson M, Ladbury JE, Davies MA, Gershenwald JE, Wagner SN, Hoon DS, Schadendorf D, Lander ES, Gabriel SB, Getz G, Garraway LA, Chin L (2012) A landscape of driver mutations in melanoma. Cell 150(2):251-263

21. Barnhill RL, Fine JA, Roush GC, Berwick M (1996) Predicting five-year outcome for patients with cutaneous melanoma in a population-based study. Cancer 78:427-432

22. Allen AC, Spitz S (1953) Malignant melanoma; a clinicopathological analysis of the criteria for diagnosis and prognosis. Cancer 6:1-45

23. Azzola MF, Shaw HM, Thompson JF, Soong SJ, Scolyer RA, Watson GF, Colman MH, Zhang Y (2003) Tumor mitotic rate is a more powerful prognostic indicator than ulceration in patients with primary cutaneous melanoma: an analysis of 3,661 patients from a single center. Cancer 97:1488-1498

24. Gimotty PA, Elder DE, Fraker DL, Botbyl J, Sellers K, Elenitsas R, Ming ME, Schuchter L, Spitz FR, Czerniecki BJ, Guerry D (2007) Identification of high-risk patients among those diagnosed with thin cutaneous melanomas. J Clin Oncol 25:1129-1134

25. Thompson JF, Soong SJ, Balch CM, Gershenwald JE, Ding S, Coit DG, Flaherty KT, Gimotty PA, Johnson T, Johnson MM, Leong SP, Ross MI, Byrd DR, Cascinelli N, Cochran AJ, Eggermont AM, McMasters KM, Mihm MC Jr, Morton DL, Sondak VK (2011) Prognostic significance of mitotic rate in localized primary cutaneous melanoma: An analysis of patients in the multi institutional American joint committee on cancer melanoma staging database. $\mathrm{J}$ Clin Oncol 29:2199-2205

26. Scolyer RA, Thompson JF (2013) Mitotic rate in melanoma should be recorded as the number of mitoses per $\mathrm{mm}(2)$ (not per high power field): surgeons tell your pathologists! Am J Surg 206:142143

27. In 't Hout FE, Haydu LE, Murali R, Bonenkamp JJ, Thompson JF, Scolyer RA (2012) Prognostic importance of the extent of ulceration in patients with clinically localized cutaneous melanoma. Ann Surg 255:1165-1170

28. Klein G, Klein E (2005) Surveillance against tumors: Is it mainly immunological? Immunol Lett 100:29-33

29. Day CL Jr, Sober AJ, Kopf AW, Lew RA, Mihm MC Jr, Golomb FM, Postel A, Hennessey P, Harris MN, Gumport SL, Raker JW, Malt RA, Cosimi AB, Wood WC, Roses DF, Gorstein F, Fitzpatrick TB (1981) A prognostic model for clinical stage I melanoma of the trunk: Location near the midline is not an independent risk factor for recurrent disease. Am J Surg 142:247-251

30. Clark WH Jr, Elder DE, Guerry D 4th, Braitman LE, Trock BJ, Schultz D, Synnestvedt M, Halpern AC (1989) Model predicting survival in stage I melanoma based on progression. J Natl Cancer Inst 81:1893-1904
31. Clemente CG, Mihm MC Jr, Bufalino R, Zurrida S, Collini P, Cascinelli N (1996) Prognostic value of tumor infiltrating lymphocytes in the vertical growth phase of primary cutaneous melanoma. Cancer 77:1303-1310

32. Taylor RC, Patel A, Panageas KS, Busam KJ, Brady MS (2007) Tumor-infiltrating lymphocytes predict sentinel lymph node positivity in patients with cutaneous melanoma. J Clin Oncol 25:869875

33. Mandalà $\mathrm{M}$, Imberti GL, Piazzalunga $\mathrm{D}$, Belfiglio $\mathrm{M}$, Labianca $\mathrm{R}$, Barberis M, Marchesi L, Poletti P, Bonomi L, Novellino L, Di Biagio K, Milesi A, Guerra U, Tondini C (2009) Clinical and histopathological risk factors to predict sentinel lymph node positivity, disease-free and overall survival in clinical stages I-II AJCC skin melanoma: Outcome analysis from a single-institution prospectively collected database. Eur J Cancer 45:2537-2545

34. Azimi F, Scolyer RA, Rumcheva P, Moncrieff M, Murali R, McCarthy SW, Saw RP, Thompson JF (2012) Tumor-infiltrating lymphocyte grade is an independent predictor of sentinel lymph node status and survival in patients with cutaneous melanoma. $\mathrm{J}$ Clin Oncol 30:2678-2683

35. Clark WH Jr, From L, Bernardino EA, Mihm MC (1969) The histogenesis and biologic behavior of primary human malignant melanomas of the skin. Cancer Res 29:705-727

36. Guitart J, Lowe L, Piepkorn M, Prieto VG, Rabkin MS, Ronan SG, Shea CR, Tron VA, White W, Barnhill RL (2002) Histological characteristics of metastasizing thin melanomas: A case-control study of 43 cases. Arch Dermatol 138:603-608

37. Blessing K, McLaren KM, McLean A, Davidson P (1990) Thin malignant melanomas (less than $1.5 \mathrm{~mm}$ ) with metastasis: A histological study and survival analysis. Histopathology 17:389-395

38. Morris KT, Busam KJ, Bero S, Patel A, Brady MS (2008) Primary cutaneous melanoma with regression does not require a lower threshold for sentinel lymph node biopsy. Ann Surg Oncol 15:316-322

39. Storr SJ, Safuan S, Mitra A, Elliott F, Walker C, Vasko MJ, Ho B, Cook M, Mohammed RA, Patel PM, Ellis IO, Newton-Bishop JA, Martin SG (2012) Objective assessment of blood and lymphatic vessel invasion and association with macrophage infiltration in cutaneous melanoma. Mod Pathol 25:493-504

40. Massi D, Puig S, Franchi A, Malvehy J, Vidal-Sicart S, GonzálezCao M, Baroni G, Ketabchi S, Palou J, Santucci M (2006) Tumour lymphangiogenesis is a possible predictor of sentinel lymph node status in cutaneous melanoma: A case-control study. J Clin Pathol 59:166-173

41. Xu X, Chen L, Guerry D, Dawson PR, Hwang WT, VanBelle P, Elder DE, Zhang PJ, Ming ME, Schuchter L, Gimotty PA (2012) Lymphatic invasion is independently prognostic of metastasis in primary cutaneous melanoma. Clin Cancer Res 18:229-237

42. Doeden K, Ma Z, Narasimhan B, Swetter SM, Detmar M, Dadras SS (2009) Lymphatic invasion in cutaneous melanoma is associated with sentinel lymph node metastasis. J Cutan Pathol 36:772-780

43. Xu X, Gimotty PA, Guerry D, Karakousis G, Van Belle P, Liang H, Montone K, Pasha T, Ming ME, Acs G, Feldman M, Barth S, Hammond R, Elenitsas R, Zhang PJ, Elder DE (2008) Lymphatic invasion revealed by multispectral imaging is common in primary melanomas and associates with prognosis. Hum Pathol 39:901-909

44. Valencak J, Heere-Ress E, Kopp T, Schoppmann SF, Kittler H, Pehamberger H (2004) Selective immunohistochemical staining shows significant prognostic influence of lymphatic and blood vessels in patients with malignant melanoma. Eur J Cancer 40:358-364

45. Yun SJ, Gimotty PA, Hwang WT, Dawson P, Van Belle P, Elder DE, Elenitsas R, Schuchter L, Zhang PJ, Guerry D, Xu X (2011) High lymphatic vessel density and lymphatic invasion underlie the adverse prognostic effect of radial growth phase regression in melanoma. Am J Surg Pathol 35:235-242 
46. Rose AE, Christos PJ, Lackaye D, Shapiro RL, Berman R, Mazumdar M, Kamin H, Osman I, Darvishian F (2011) Clinical relevance of detection of lymphovascular invasion in primary melanoma using endothelial markers D2-40 and CD34. Am J Surg Pathol 35:1441-1449

47. Petersson F, Diwan AH, Ivan D, Gershenwald JE, Johnson MM, Harrell R, Prieto VG (2009) Immunohistochemical detection of lymphovascular invasion with D2-40 in melanoma correlates with sentinel lymph node status, metastasis and survival. J Cutan Pathol 36:1157-1163

48. Cook MG, Green MA, Anderson B, Eggermont AM, Ruiter DJ, Spatz A, Kissin MW, Powell BW, EORTC Melanoma Group (2003) The development of optimal pathological assessment of sentinel lymph nodes for melanoma. J Pathol 200:314-319

49. van Akkooi AC, de Wilt JH, Verhoef C, Schmitz PI, van Geel AN, Eggermont AM, Kliffen M (2006) Clinical relevance of melanoma micrometastases $(<0.1 \mathrm{~mm})$ in sentinel nodes: are these nodes to be considered negative? Ann Oncol 17:1578-1585

50. van der Ploeg AP, van Akkooi AC, Schmitz PI, Koljenovic S, Verhoef C, Eggermont AM (2010) EORTC melanoma group sentinel node protocol identifies high rate of submicrometastases according to Rotterdam criteria. Eur J Cancer 46:2414-2421

51. Balch CM, Gershenwald JE, Soong SJ, Thompson JF, Ding S, Byrd DR, Cascinelli N, Cochran AJ, Coit DG, Eggermont AM, Johnson T, Kirkwood JM, Leong SP, McMasters KM, Mihm MC Jr, Morton DL, Ross MI, Sondak VK (2010) Multivariate analysis of prognostic factors among 2,313 patients with stage III melanoma: Comparison of nodal micrometastases versus macrometastases. J Clin Oncol 28:2452-2459

52. van der Ploeg AP, van Akkooi AC, Rutkowski P, Nowecki ZI, Michej W, Mitra A, Newton-Bishop JA, Cook M, van der Ploeg IM, Nieweg OE, van den Hout MF, van Leeuwen PA, Voit CA, Cataldo F, Testori A, Robert C, Hoekstra HJ, Verhoef C, Spatz A, Eggermont AM (2011) Prognosis in patients with sentinel nodepositive melanoma is accurately defined by the combined Rotterdam tumor load and Dewar topography criteria. J Clin Oncol 29:2206-2214

53. Alonso SR, Ortiz P, Pollán M, Pérez-Gómez B, Sánchez L, Acuña MJ, Pajares R, Martínez-Tello FJ, Hortelano CM, Piris MA, Rodríguez-Peralto JL (2004) Progression in cutaneous malignant melanoma is associated with distinct expression profiles: A tissue microarray-based study. Am J Pathol 164:193-203

54. Alonso SR, Tracey L, Ortiz P, Pérez-Gómez B, Palacios J, Pollán M, Linares J, Serrano S, Sáez-Castillo AI, Sánchez L, Pajares R, Sánchez-Aguilera A, Artiga MJ, Piris MA, Rodríguez-Peralto JL (2007) A high-throughput study in melanoma identifies epithelialmesenchymal transition as a major determinant of metastasis. Cancer Res 67:3450-3460

55. Berger AJ, Kluger HM, Li N, Kielhorn E, Halaban R, Ronai Z, Rimm DL (2003) Subcellular localization of activating transcription factor 2 in melanoma specimens predicts patient survival. Cancer Res 63:8103-8107

56. Florenes VA, Maelandsmo GM, Faye R, Nesland JM, Holm R (2001) Cyclin a expression in superficial spreading malignant melanomas correlates with clinical outcome. J Pathol 195:530-536

57. Florenes VA, Faye RS, Maelandsmo GM, Nesland JM, Holm R (2000) Levels of cyclin D1 and D3 in malignant melanoma: Deregulated cyclin D3 expression is associated with poor clinical outcome in superficial melanoma. Clin Cancer Res 6:3614-3620

58. Li Q, Murphy M, Rossi J, Sheehan C, Carlson JA (2004) Skp2 and p27kip1 expression in melanocytic nevi and melanoma: An inverse relationship. J Cutan Pathol 31:633-642

59. Niezabitowski A, Czajecki K, Ryś J, Kruczak A, Gruchała A, Wasilewska A, Lackowska B, Sokołowski A, Szklarski W (1999) Prognostic evaluation of cutaneous malignant melanoma: A clinicopathologic and immunohistochemical study. J Surg Oncol 70:150-160

60. Rangel J, Torabian S, Shaikh L, Nosrati M, Baehner FL, Haqq C, Leong SP, Miller JR 3rd, Sagebiel RW, Kashani-Sabet M (2006) Prognostic significance of nuclear receptor coactivator-3 overexpression in primary cutaneous melanoma. J Clin Oncol 24: 4565-4569

61. Straume O, Akslen LA (2005) Strong expression of ID1 protein is associated with decreased survival, increased expression of ephrinA1/EPHA2, and reduced thrombospondin-1 in malignant melanoma. Br J Cancer 93:933-938

62. Straume O, Sviland L, Akslen LA (2000) Loss of nuclear p16 protein expression correlates with increased tumor cell proliferation (Ki-67) and poor prognosis in patients with vertical growth phase melanoma. Clin Cancer Res 6:1845-1853

63. Piras F, Perra MT, Murtas D, Minerba L, Floris C, Maxia C, Demurtas P, Ugalde J, Ribatti D, Sirigu P (2008) Combinations of apoptosis and cell-cycle control biomarkers predict the outcome of human melanoma. Oncol Rep 20:271-277

64. Rangel J, Nosrati M, Leong SP, Haqq C, Miller JR 3rd, Sagebiel RW, Kashani-Sabet M (2008) Novel role for RGS1 in melanoma progression. Am J Surg Pathol 32:1207-1212

65. Reschke M, Mihic-Probst D, van der Horst EH, Knyazev P, Wild PJ, Hutterer M, Meyer S, Dummer R, Moch H, Ullrich A (2008) HER3 is a determinant for poor prognosis in melanoma. Clin Cancer Res 14:5188-5197

66. Ladstein RG, Bachmann IM, Straume O, Akslen LA (2010) Ki-67 expression is superior to mitotic count and novel proliferation markers PHH3, MCM4 and mitosin as a prognostic factor in thick cutaneous melanoma. BMC Cancer 10:140

67. Ladstein RG, Bachmann IM, Straume O, Akslen LA (2012) Prognostic importance of the mitotic marker phosphohistone H3 in cutaneous nodular melanoma. J Invest Dermatol 132:1247-1252

68. Chen G, Cheng Y, Zhang Z, Martinka M, Li G (2011) Cytoplasmic Skp2 expression is increased in human melanoma and correlated with patient survival. PLoS One 6:e17578

69. Gimotty PA, Van Belle P, Elder DE, Murry T, Montone KT, Xu X, Hotz S, Raines S, Ming ME, Wahl P, Guerry D (2005) Biologic and prognostic significance of dermal Ki67 expression, mitoses, and tumorigenicity in thin invasive cutaneous melanoma. J Clin Oncol 23:8048-8056

70. Berger AJ, Davis DW, Tellez C, Prieto VG, Gershenwald JE, Johnson MM, Rimm DL, Bar-Eli M (2005) Automated quantitative analysis of activator protein-2alpha subcellular expression in melanoma tissue microarrays correlates with survival prediction. Cancer Res 65:11185-11192

71. Berger AJ, Camp RL, Divito KA, Kluger HM, Halaban R, Rimm DL (2004) Automated quantitative analysis of HDM2 expression in malignant melanoma shows association with early-stage disease and improved outcome. Cancer Res 64:8767-8772

72. Karjalainen JM, Kellokoski JK, Eskelinen MJ, Alhava EM, Kosma VM (1998) Downregulation of transcription factor AP-2 predicts poor survival in stage I cutaneous malignant melanoma. J Clin Oncol 16:3584-3591

73. Korabiowska M, Tscherny M, Stachura J, Berger H, Cordon-Cardo C, Brinck U (2002) Differential expression of DNA nonhomologous end-joining proteins $\mathrm{Ku} 70$ and $\mathrm{Ku} 80$ in melanoma progression. Mod Pathol 15:426-433

74. McDermott NC, Milburn C, Curran B, Kay EW, Barry Walsh C, Leader MB (2000) Immunohistochemical expression of $n m 23$ in primary invasive malignant melanoma is predictive of survival outcome. J Pathol 190:157-162

75. Pacifico MD, Grover R, Richman PI, Buffa F, Daley FM, Wilson GD (2005) $\mathrm{nm} 23$ as a prognostic marker in primary cutaneous melanoma: Evaluation using tissue microarray in a patient group with long-term follow-up. Melanoma Res 15:435-440 
76. Soltani MH, Pichardo R, Song Z, Sangha N, Camacho F, Satyamoorthy K, Sangueza OP, Setaluri V (2005) Microtubuleassociated protein 2, a marker of neuronal differentiation, induces mitotic defects, inhibits growth of melanoma cells, and predicts metastatic potential of cutaneous melanoma. Am J Pathol 166:1841-1850

77. Li J, Martinka M, Li G (2008) Role of ING4 in human melanoma cell migration, invasion and patient survival. Carcinogenesis 29: 1373-1379

78. Lin H, Wong RPC, Martinka M, Li G (2009) Loss of SNF5 expression correlates with poor patient survival in melanoma. Clin Cancer Res 15:6404-6411

79. Jonsson L, Bergman J, Nodin B, Manjer J, Pontén F, Uhlén M, Jirström K (2011) Low RBM3 protein expression correlates with tumour progression and poor prognosis in malignant melanoma: An analysis of 215 cases from the malmö diet and cancer study. J Transl Med 9:114

80. Jafarnejad SM, Wani AA, Martinka M, Li G (2010) Prognostic significance of Sox 4 expression in human cutaneous melanoma and its role in cell migration and invasion. Am J Pathol 177:2741-2752

81. Chen H, Takahara M, Oba J, Xie L, Chiba T, Takeuchi S, Tu Y, Nakahara T, Uchi H, Moroi Y, Furue M (2011) Clinicopathologic and prognostic significance of SATB1 in cutaneous malignant melanoma. J Dermatol Sci 64:39-44

82. Divito KA, Berger AJ, Camp RL, Dolled-Filhart M, Rimm DL, Kluger HM (2004) Automated quantitative analysis of tissue microarrays reveals an association between high Bcl-2 expression and improved outcome in melanoma. Cancer Res 64:8773-8777

83. Ekmekcioglu S, Ellerhorst JA, Prieto VG, Johnson MM, Broemeling LD, Grimm EA (2006) Tumor iNOS predicts poor survival for stage III melanoma patients. Int J Cancer 119:861-866

84. Bachmann IM, Ladstein RG, Straume O, Naumov GN, Akslen LA (2008) Tumor necrosis is associated with increased alphavbeta3 integrin expression and poor prognosis in nodular cutaneous melanomas. BMC Cancer 8:362

85. Piras F, Murtas D, Minerba L, Ugalde J, Floris C, Maxia C, Colombari R, Perra MT, Sirigu P (2007) Nuclear survivin is associated with disease recurrence and poor survival in patients with cutaneous malignant melanoma. Histopathology 50:835-842

86. Zhuang L, Scolyer RA, Lee CS, McCarthy SW, Cooper WA, Zhang XD, Thompson JF, Hersey P (2009) Expression of glucoseregulated stress protein GRP78 is related to progression of melanoma. Histopathology 54:462-470

87. Bittner M, Meltzer P, Chen Y, Jiang Y, Seftor E, Hendrix M, Radmacher M, Simon R, Yakhini Z, Ben-Dor A, Sampas N, Dougherty E, Wang E, Marincola F, Gooden C, Lueders J, Glatfelter A, Pollock P, Carpten J, Gillanders E, Leja D, Dietrich K, Beaudry C, Berens M, Alberts D, Sondak V (2000) Molecular classification of cutaneous malignant melanoma by gene expression profiling. Nature 406(6795):536-540

88. Tremante E, Ginebri A, Lo Monaco E, Frascione P, Di Filippo F, Terrenato I, Benevolo M, Mottolese M, Pescarmona E, Visca P, Natali PG, Giacomini P (2012) Melanoma molecular classes and prognosis in the postgenomic era. Lancet Oncol 13(5):e205-e211

89. Mandruzzato S, Callegaro A, Turcatel G, Francescato S, Montesco MC, Chiarion-Sileni V, Mocellin S, Rossi CR, Bicciato S, Wang E, Marincola FM, Zanovello P (2006) A gene expression signature associated with survival in metastatic melanoma. J Transl Med 4:50

90. Winnepenninckx V, Lazar V, Michiels S, Dessen P, Stas M, Alonso SR, Avril MF, Ortiz Romero PL, Robert T, Balacescu O, Eggermont AM, Lenoir G, Sarasin A, Tursz T, van den Oord JJ, Spatz A, Melanoma Group of the European Organization for Research and Treatment of Cancer (2006) Gene expression profiling of primary cutaneous melanoma and clinical outcome. J Natl Cancer Inst 98: $472-482$

91. Soikkeli J, Lukk M, Nummela P, Virolainen S, Jahkola T, Katainen R, Harju L, Ukkonen E, Saksela O, Hölttä E (2007) Systematic search for the best gene expression markers for melanoma micrometastasis detection. J Pathol 213:180-189

92. Brunner G, Reitz M, Schwipper V, Tilkorn H, Lippold A, Biess B, Suter L, Atzpodien J (2008) Increased expression of the tumor suppressor PLZF is a continuous predictor of long-term survival in malignant melanoma patients. Cancer Biother Radiopharm 23:451459

93. John T, Black MA, Toro TT, Leader D, Gedye CA, Davis ID, Guilford PJ, Cebon JS (2008) Predicting clinical outcome through molecular profiling in stage III melanoma. Clin Cancer Res 14:51735180

94. Kauffmann A, Rosselli F, Lazar V, Winnepenninckx V, MansuetLupo A, Dessen P, van den Oord JJ, Spatz A, Sarasin A (2008) High expression of DNA repair pathways is associated with metastasis in melanoma patients. Oncogene 27:565-573

95. Bogunovic D, O'Neill DW, Belitskaya-Levy I, Vacic V, Yu YL, Adams S, Darvishian F, Berman R, Shapiro R, Pavlick AC, Lonardi S, Zavadil J, Osman I, Bhardwaj N (2009) Immune profile and mitotic index of metastatic melanoma lesions enhance clinical staging in predicting patient survival. Proc Natl Acad Sci U S A 106: 20429-20434

96. Conway C, Mitra A, Jewell R, Randerson-Moor J, Lobo S, Nsengimana J, Edward S, Sanders DS, Cook M, Powell B, Boon A, Elliott F, de Kort F, Knowles MA, Bishop DT, Newton-Bishop J (2009) Gene expression profiling of paraffin-embedded primary melanoma using the DASL assay identifies increased osteopontin expression as predictive of reduced relapse-free survival. Clin Cancer Res 15:6939-6946

97. Haqq C, Nosrati M, Sudilovsky D, Crothers J, Khodabakhsh D, Pulliam BL, Federman S, Miller JR 3rd, Allen RE, Singer MI, Leong SP, Ljung BM, Sagebiel RW, Kashani-Sabet M (2005) The gene expression signatures of melanoma progression. Proc Natl Acad Sci U S A 102:6092-6097

98. Caramuta S, Egyházi S, Rodolfo M, Witten D, Hansson J, Larsson C, Lui WO (2010) MicroRNA expression profiles associated with mutational status and survival in malignant melanoma. J Invest Dermatol 130:2062-2070

99. Segura MF, Belitskaya-Lévy I, Rose AE, Zakrzewski J, Gaziel A, Hanniford D, Darvishian F, Berman RS, Shapiro RL, Pavlick AC, Osman I, Hernando E (2010) Melanoma microRNA signature predicts post-recurrence survival. Clin Cancer Res 16:1577-1586

100. Mauerer A, Roesch A, Hafner C, Stempfl T, Wild P, Meyer S, Landthaler M, Vogt T (2011) Identification of new genes associated with melanoma. Exp Dermatol 20:502-507

101. Ferrier CM, Suciu S, van Geloof WL, Straatman H, Eggermont AM, Koops HS, Kroon BB, Lejeune FJ, Kleeberg UR, van Muijen GN, Ruiter DJ (2000) High tPA-expression in primary melanoma of the limb correlates with good prognosis. Br J Cancer 83:1351-1359

102. Ilmonen S, Jahkola T, Turunen JP, Muhonen T, Asko-Seljavaara S (2004) Tenascin-C in primary malignant melanoma of the skin. Histopathology 45:405-411

103. Karjalainen JM, Tammi RH, Tammi MI, Eskelinen MJ, Agren UM, Parkkinen JJ, Alhava EM, Kosma VM (2000) Reduced level of CD44 and hyaluronan associated with unfavorable prognosis in clinical stage I cutaneous melanoma. Am J Pathol 157:957-965

104. Pacifico MD, Grover R, Richman PI, Daley FM, Buffa F, Wilson GD (2006) CD44v3 levels in primary cutaneous melanoma are predictive of prognosis: assessment by the use of tissue microarray. Int J Cancer 118:1460-1464

105. Pacifico MD, Grover R, Richman PI, Buffa F, Daley FM, Wilson GD (2005) Identification of P-cadherin in primary melanoma using a tissue microarrayer: Prognostic implications in a patient cohort with long-term follow up. Ann Plast Surg 55:316-320

106. Pacifico MD, Grover R, Richman PI, Daley FM, Buffa F, Wilson GD (2005) Development of a tissue array for primary melanoma with long-term follow-up: Discovering melanoma cell adhesion 
molecule as an important prognostic marker. Plast Reconstr Surg 115:367-375

107. Pearl RA, Pacifico MD, Richman PI, Wilson GD, Grover R (2008) Stratification of patients by melanoma cell adhesion molecule (MCAM) expression on the basis of risk: Implications for sentinel lymph node biopsy. J Plast Reconstr Aesthet Surg 61:265-271

108. Rangel J, Nosrati M, Torabian S, Shaikh L, Leong SP, Haqq C, Miller JR 3rd, Sagebiel RW, Kashani-Sabet M (2008) Osteopontin as a molecular prognostic marker for melanoma. Cancer 112:144-150

109. Scala S, Ottaiano A, Ascierto PA, Cavalli M, Simeone E, Giuliano P, Napolitano M, Franco R, Botti G, Castello G (2005) Expression of CXCR4 predicts poor prognosis in patients with malignant melanoma. Clin Cancer Res 11:1835-1841

110. Thies A, Schachner M, Moll I, Berger J, Schulze HJ, Brunner G, Schumacher U (2002) Overexpression of the cell adhesion molecule $\mathrm{L} 1$ is associated with metastasis in cutaneous malignant melanoma. Eur J Cancer 38:1708-1716

111. Thies A, Moll I, Berger J, Wagener C, Brümmer J, Schulze HJ, Brunner G, Schumacher U (2002) CEACAM1 expression in cutaneous malignant melanoma predicts the development of metastatic disease. J Clin Oncol 20:2530-2536

112. Weinlich G, Eisendle K, Hassler E, Baltaci M, Fritsch PO, Zelger B (2006) Metallothionein - overexpression as a highly significant prognostic factor in melanoma: A prospective study on 1270 patients. Br J Cancer 94:835-841

113. Weinlich G, Topar G, Eisendle K, Fritsch PO, Zelger B (2007) Comparison of metallothionein-overexpression with sentinel lymph node biopsy as prognostic factors in melanoma. J Eur Acad Dermatol Venereol 21:669-677

114. Bachmann IM, Ladstein RG, Straume O, Naumov GN, Akslen LA (2008) Tumor necrosis is associated with increased alpha(v)beta(3) integrin expression and poor prognosis in nodular cutaneous melanomas. BMC Cancer 8:1-10

115. Boone B, Van Gele M, Lambert J, Haspeslagh M, Brochez L (2009) The role of RhoC in growth and metastatic capacity of melanoma. J Cutan Pathol 36:629-636

116. Kreizenbeck GM, Berger AJ, Subtil A, Rimm DL, Gould Rothberg BE (2008) Prognostic significance of cadherin-based adhesion molecules in cutaneous malignant melanoma. Cancer Epidemiol Biomarkers Prev 17:949-958

117. Buljan M, Šitum M, Tomas D, Milošević M, Krušlin B (2011) Prognostic value of galectin-3 in primary cutaneous melanoma. J Eur Acad Dermatol Venereol 25:1174-1181

118. Lade-Keller J, Riber-Hansen R, Guldberg P, Schmidt H, HamiltonDutoit SJ, Steiniche T (2013) E- to N-cadherin switch in melanoma is associated with decreased expression of PTEN and cancer progression. Br J Dermatol. doi:10.1111/bjd.12426

119. Bachmann IM, Puntervoll HE, Otte AP, Akslen LA (2008) Loss of BMI-1 expression is associated with clinical progress of malignant melanoma. Mod Pathol 21:583-590

120. Straume O, Jackson DG, Akslen LA (2003) Cutaneous melanoma and presence of low-grade lymphangiogenesis in independent prognostic impact of lymphatic vessel density. Clin Cancer Res 9:250-256

121. Zhuang L, Scolyer RA, Murali R, McCarthy SW, Zhang XD, Thompson JF, Hersey P (2010) Lactate dehydrogenase 5 expression in melanoma increases with disease progression and is associated with expression of Bcl-XL and Mcl-1, but not Bcl-2 proteins. Mod Pathol 23:45-53

122. Hofbauer GF, Burkhart A, Schuler G, Dummer R, Burg G, Nestle FO (2004) High frequency of melanoma-associated antigen or HLA class I loss does not correlate with survival in primary melanoma. J Immunother 27:73-78

123. Svobodová S, Browning J, MacGregor D, Pollara G, Scolyer RA, Murali R, Thompson JF, Deb S, Azad A, Davis ID, Cebon JS (2011) Cancer-testis antigen expression in primary cutaneous melanoma has independent prognostic value comparable to that of breslow thickness, ulceration and mitotic rate. Eur J Cancer 47:460-469

124. Kashani-Sabet M, Venna S, Nosrati M, Rangel J, Sucker A, Egberts F, Baehner FL, Simko J, Leong SP, Haqq C, Hauschild A, Schadendorf D, Miller JR 3rd, Sagebiel RW (2009) A multimarker prognostic assay for primary cutaneous melanoma. Clin Cancer Res 15:6987-6992

125. Gould Rothberg BE, Berger AJ, Molinaro AM, Subtil A, Krauthammer MO, Camp RL, Bradley WR, Ariyan S, Kluger HM, Rimm DL (2009) Melanoma prognostic model using tissue microarrays and genetic algorithms. J Clin Oncol 27:5772-5780

126. Lawrence MS, Stojanov P, Polak P, Kryukov GV, Cibulskis K, Sivachenko A, Carter SL, Stewart C, Mermel CH, Roberts SA, Kiezun A, Hammerman PS, McKenna A, Drier Y, Zou L, Ramos AH, Pugh TJ, Stransky N, Helman E, Kim J, Sougnez C, Ambrogio L, Nickerson E, Shefler E, Cortés ML, Auclair D, Saksena G, Voet D, Noble M, DiCara D, Lin P, Lichtenstein L, Heiman DI, Fennell T, Imielinski M, Hernandez B, Hodis E, Baca S, Dulak AM, Lohr J, Landau DA, Wu CJ, Melendez-Zajgla J, Hidalgo-Miranda A, Koren A, McCarroll SA, Mora J, Lee RS, Crompton B, Onofrio R, Parkin M, Winckler W, Ardlie K, Gabriel SB, Roberts CW, Biegel JA, Stegmaier K, Bass AJ, Garraway LA, Meyerson M, Golub TR, Gordenin DA, Sunyaev S, Lander ES, Getz G (2013) Mutational heterogeneity in cancer and the search for new cancer-associated genes. Nature 499(7457):214-218

127. Flaherty KT, Hodi FS, Bastian BC (2010) Mutation-driven drug development in melanoma. Curr Opin Oncol 22:178-183

128. Davies H, Bignell GR, Cox C, Stephens P, Edkins S, Clegg S, Teague J, Woffendin H, Garnett MJ, Bottomley W, Davis N, Dicks E, Ewing R, Floyd Y, Gray K, Hall S, Hawes R, Hughes J, Kosmidou V, Menzies A, Mould C, Parker A, Stevens C, Watt S, Hooper S, Wilson R, Jayatilake H, Gusterson BA, Cooper C, Shipley J, Hargrave D, Pritchard-Jones K, Maitland N, ChenevixTrench G, Riggins GJ, Bigner DD, Palmieri G, Cossu A, Flanagan A, Nicholson A, Ho JW, Leung SY, Yuen ST, Weber BL, Seigler HF, Darrow TL, Paterson H, Marais R, Marshall CJ, Wooster R, Stratton MR, Futreal PA (2002) Mutations of the BRAF gene in human cancer. Nature 417:949-954

129. Safaee Ardekani G, Jafarnejad SM, Tan L, Saeedi A, Li G (2012) The prognostic value of BRAF mutation in colorectal cancer and melanoma: A systematic review and meta-analysis. PLoS One 7:e47054

130. Ellerhorst JA, Greene VR, Ekmekcioglu S, Warneke CL, Johnson MM, Cooke CP, Wang LE, Prieto VG, Gershenwald JE, Wei Q, Grimm EA (2011) Clinical correlates of NRAS and BRAF mutations in primary human melanoma. Clin Cancer Res 17:229-235

131. Edlundh-Rose E, Egyházi S, Omholt K, Månsson-Brahme E, Platz A, Hansson J, Lundeberg J (2006) BRAF mutations in melanoma tumours in relation to clinical characteristics: A study based on mutation screening by pyrosequencing. Melanoma Res 16:471-478

132. Long GV, Menzies AM, Nagrial AM, Haydu LE, Hamilton AL, Mann GJ, Hughes TM, Thompson JF, Scolyer RA, Kefford RF (2011) Prognostic and clinicopathologic associations of oncogenic BRAF in metastatic melanoma. J Clin Oncol 29:1239-1246

133. Si L, Kong Y, Xu X (2012) Prevalence of BRAF V600E mutation in Chinese melanoma patients: Large scale analysis of BRAF and NRAS mutations in a 432-case cohort. Eur J Cancer 48:94-100

134. Devitt B, Liu W, Salemi R, Wolfe R, Kelly J, Tzen CY, Dobrovic A, McArthur G (2011) Clinical outcome and pathological features associated with NRAS mutation in cutaneous melanoma. Pigment Cell Melanoma Res 24:666-672

135. Mann GJ, Pupo GM, Campain AE, Carter CD, Schramm SJ, Pianova S, Gerega SK, De Silva C, Lai K, Wilmott JS, Synnott M, Hersey P, Kefford RF, Thompson JF, Yang YH, Scolyer RA (2013) BRAF mutation, NRAS mutation, and the absence of an immune-related expressed gene profile predict poor outcome in patients with stage III melanoma. J Invest Dermatol 133:509-517 